Opinion

\title{
Simple solution for control air pollution in the cities and our metabolism
}

Keywords: Air Pollution; Metabolism; Asthma; Bronchitis; Mental disturbance; Skin diseases; Pollutions; Humidity; Wastage

\section{Opinion}

Air pollution in all cities is big problem throughout year. Now it is looking very high in Delhi. By Air pollutions people's gets many kind of diseases like Asthma, Bronchitis, Mental disturbance, Skin diseases, and it's also affect our metabolism. Now I am giving some permanent solutions that every Chou k (circle) we must put a big Rain fall to clean the air and control the weather. Because water has capacity to suck the pollution from the air control the humidity temperature. And increase the green vegetable and tree. According to my knowledge Bamboo Is very fast growing Plant (grass) in the world and it has big capacity to absorb pollution's and produces oxygen. By putting this kind of plant we can control pollution we must make cities in a plan way. We can use solar vehicle or battery vehicle in the place of petrol and diesel vehicle; we can use night soil and wastage of green vegetables for cooking gas. Because night soil, green vegetables, cow done produces methane gas. In other side we can use the wastage of green vegetables like Plants leafs, Green grass. Orange roughage Sugarcane waste etc in clean way then we can use it for animal's fodders and we can produces milk and meat. I saw many cities administrations make places for throwing wastes and not a systematic way and people throwing not a clean way even then animals eating the wastage but not a whole after some time its produce smell. We can see the garbage in the corner of cities and

\author{
Volume 3 Issue 6 - 2016
}

\section{Pramod Stephen}

Wellness and Fitness Professional, L.N.D. College, India

Correspondence: Pramod Stephen, Innovator, Wellness and Fitness Professional, Christian Colony, Ward No.6, Siswaniya Tola, P.O. Sugauli 845456, East Champaran, Bihar, India, Tel +9l 9199646455,Email pramod_stephen@rediffmail.com

Received: November 25, 2016 | Published: November 29, 2016

it is big problems of all cities. If we can plan for recycling of our green wastages, Night soils, Glasses, Plastic, Cloths, water, leathers, furniture's, Rubber's, Bricks, woods, and other useless substance in such a way then we can control much kind of pollutions in the cities.

\section{Acknowledgments}

None.

\section{Conflicts of interest}

The author declares there are no conflicts of interest. 